\title{
Trypanosoma cruzi Infection in Didelphis marsupialis in Santa Catarina and Arvoredo Islands, Southern Brazil
}

\author{
Edmundo C Grisard ${ }^{+}$, Carlos J Carvalho-Pinto, Afonso F Scholz, \\ Helena K Toma, Bruno R Schlemper Jr, Mário Steindel
}

\author{
Departamento de Microbiologia, Imunologia e Parasitologia, Universidade Federal de Santa Catarina, \\ Caixa Postal 476, 88040-900 Florianópolis, SC, Brasil
}

Between 1984 and 1993 the prevalence of the Trypanosoma cruzi infection in opossums (Didelphis marsupialis) was studied in Santa Catarina and Arvoredo Islands, State of Santa Catarina, Brazil. The association of the triatomine bug Panstrongylus megistus with opossums nests and the infection rate of these triatomines by T. cruzi was also studied. Thirteen different locations were studied in Santa Catarina Island (SCI), in which 137 D. marsupialis were collected. Sixty two opossums were collected at the Arvoredo Island (AI), located 12 miles north from SCI. All captured animals were submitted to parasitological examinations that revealed the presence of $\mathrm{T}$. cruzi in $21.9 \%$ of the opossums captured in SCI and $45.2 \%$ among opossums captured in the AI. The presence of $\mathrm{P}$. megistus was detected in most of the D. marsupialis nests collected in the SCI, however, in the non-inhabited AI only eight triatomines were collected during the whole study. The presence of $\mathrm{T}$. cruzi-infected $\mathrm{D}$. marsupialis associated with $\mathrm{P}$. megistus in human dwellings in the SCI, and the high infection rate of $\mathrm{D}$. marsupilais by T. cruzi in the absence of a high vector density are discussed.

Key words: Didelphis marsupialis - Trypanosoma cruzi - Panstrongylus megistus - Chagas disease human dwellings - Santa Catarina - Brazil

Trypanosoma cruzi, the etiological agent of Chagas disease, is a protozoan parasite that infects over 200 sylvatic or domestic mammalian species and subspecies from seven different orders in Central and South America, including man. Marsupials, mainly those from the genus Didelphis, have been cited as one of the most important reservoirs of $T$. cruzi in several Latin American countries (Barretto et al. 1964, Travi et al. 1994). Previous studies revealed distinct infection rates of Didelphis sp. by T. cruzi in different regions of Brazil such as $35.7 \%$ in Rio de Janeiro (Guimarães \& Jansen 1943), 24\% in the Amazon basin (Miles 1976), 20.6\% in Mambaí, State of Goiás (Mello 1982) and 37.9\% in Bambuí, State of Minas Gerais (Fernandes et al. 1991).

Due to its synantropic behaviour, frequently invading human dwellings in both rural and urban areas, opossums are commonly bitten by sylvatic and/or peridomestic triatomine species. Once infected by $T$. cruzi these marsupials usually present

\footnotetext{
${ }^{+}$Corresponding author. Fax: +55-48-331.9258. E-mail: grisard@ccb.ufsc.br

Received 15 February 2000

Accepted 19 June 2000
}

high infection rates and long term parasitemia, acting as important links between the parasite sylvatic and domestic transmission cycles (Barretto et al. 1964, Zeledon et al. 1970).

Although the State of Santa Catarina is nonendemic for human Chagas disease, previous studies revealed that $84.5 \%$ and $66.6 \%$ of the $P$. megistus and Rhodnius domesticus were infected by T. cruzi, respectively (Schlemper Jr et al. 1985). Recently, adults and nymphs of $P$. megistus were found in several artificial ecotopes as well as in human dwellings in Santa Catarina Island (SCI), indicating the high potential of this species to invade and colonize human dwellings as observed in the State of São Paulo (Forattini et al. 1982, Steindel et al. 1994).

In this work we studied the prevalence of $T$. cruzi among $D$. marsupialis $(=D$. aurita) captured in two distinct islands in Santa Catarina as well as discuss the presence of this opossum associated with $P$. megistus in human dwellings as an important risk factor for the transmission of Chagas disease.

\section{MATERIALS AND METHODS}

Study site - SCI, also known as Florianópolis, has an area of $425 \mathrm{~km}^{2}$ and is located in Santa Catarina, southern Brazil. Around 500,000 people live nowadays in this Island where only $15-20 \%$ of the original Atlantic forest remains intact. For 


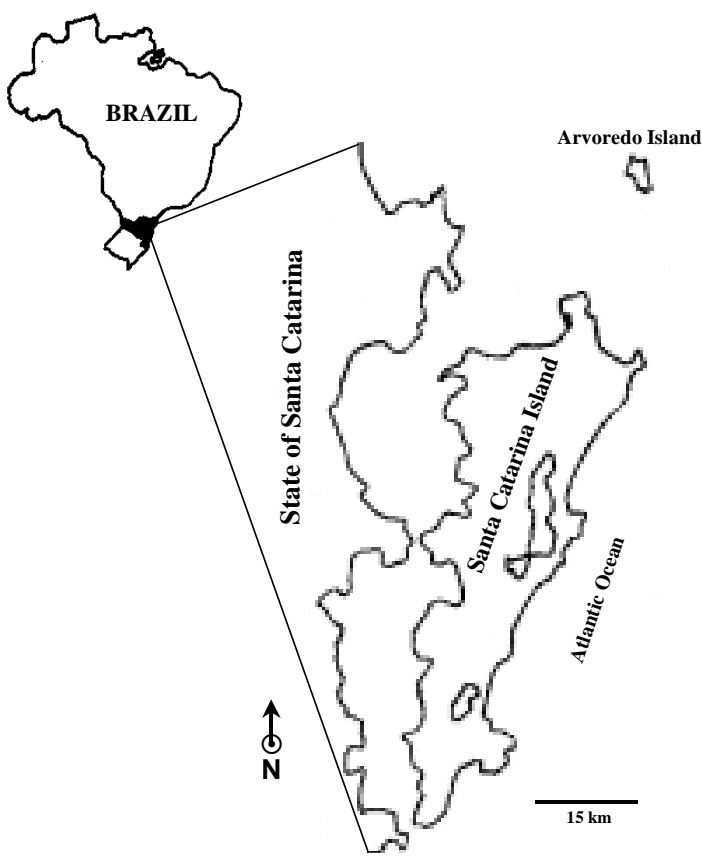

Map showing the Arvoredo and Santa Catarina Islands localization off the State of Santa Catarina coast.

this study, SCI was divided in north, central and south regions, and 13 localities were studied. Arvoredo Island (AI), with a $7 \mathrm{~km}^{2}$ area, is located 12 miles north from the SCI, mostly covered by a well-conserved forest. In the AI, a Brazilian navy base (Marinha do Brasil) has only a few men (3-5) which usually stay periods of 12-24 months in it (Figure).

Animal captures - Animals were collected in both islands from 1984 up to 1993, manually or with live-traps $(20 \times 20 \times 60 \mathrm{~cm})$ set up in sylvatic, peri-domestic or domestic environments as described by Fernandes et al. (1990). Animals captured by inhabitants were also included in this study. After sex and weight determination, each animal was subjected to parasitological examinations to detect $T$. cruzi infection. Both fresh and Giemsa-stained smears, hemoculture in LIT (liver infusion tryptose) medium as described by Luz et al. (1994) and xenodiagnosis performed with 15 nymphs of 4 th $/ 5$ th instar of $P$. megistus was used to detect $T$. cruzi infection.

Whenever possible, the scent glands were examined for the presence of $T$. cruzi. Other marsupial and rodent species were captured in both islands during this study. These animals were also examined for $T$. cruzi infection as described above.

Animals captured in the AI were either examined in the field or brought to the laboratory. Thirty- five opossums captured in the AI were tagged and released for recapture after four to six months. For nest localization, six adult $D$. marsupilais were followed using the method described by Miles (1976). Briefly, this method uses a backpack attached to the opossum, which contains a line reel. The animal is released in the same capturing site and the line tracked to the end. Comparison of the percentage of infected animals in both islands was performed by the chi-square $\left(\chi^{2}\right)$ test.

Triatomine search - In both islands, triatomines were systematically searched in opossums nests in tree holes, rocks, palm trees and bromeliads in both sylvatic or peri-domiciliar environment and also in houses and other human-made dwellings. In the $\mathrm{AI}$, triatomines were also captured using light traps. All captured triatomines had their intestinal contents and feces examined for the presence of flagellates by fresh and Giemsa-stained smears. T. cruzi was isolated by sub-inoculation of positive feces in Swiss albino mice or by xenoculture as previously described (Bronfen et al. 1989).

\section{RESULTS}

A total of 199 D. marsupialis were collected in both islands, 137 (63 males, 70 females and 4 undetermined) at the SCI and 62 (27 males and 35 females) at the AI. The T. cruzi infection rate among these animals was $21.9 \%$ and $45.2 \%$, respectively (Table).

At SCI, 13 out of 137 animals were positive by fresh blood examination (9.5\%), 25 by xenodiagnosis $(18.2 \%)$ and 21 by hemoculture $(15.3 \%)$ in a total of 30 T. cruzi positive opossums. Among all D. marsupialis captured in SCI, mostly from Lagoa da Conceição, Trindade and Córrego Grande localities (Central region), $27.7 \%$ of them were captured in human dwellings (houses and annexes), $17.5 \%$ in the peridomicile (storage houses) and $45.2 \%$ in the sylvatic environment (Table). No $T$. cruzi infection in scent glands was detected among 71 animals examined in this island. T. cruzi infection was found in $12.4 \%$ of the opossums captured in human-related dwellings.

Two other marsupial species (Lutreolina crassicaudata and Marmosa cinerea) were captured in SCI. No T. cruzi infection was detected among the 34 captured animals ( 28 L. crassicaudata and six M. cinerea).

At the AI, six out of 62 opossums were positive for $T$. cruzi by fresh blood examination $(9.7 \%)$, 28 by xenodiagnosis $(45.2 \%)$ and 12 by hemoculture $(19.3 \%)$. Among the 28 T. cruzi-positive $D$. marsupialis, two had parasites in the scent glands $(7.1 \%)$, as determined by fresh and Giemsastained smears. All positive samples were isolated by culture in LIT medium. The number of infected 
TABLE

Number of Didelphis marsupialis captured in Santa Catarina and Arvoredo Islands, the percentage of Trypanosoma cruzi infected animals and the number of captured and $T$. cruzi positive animals per ecotope

\begin{tabular}{lrcrrr}
\hline & $\begin{array}{c}\text { Total } \\
\text { number }\end{array}$ & $\begin{array}{l}\text { T. cruzi } \\
\text { infected }\end{array}$ & House & Annexes & Forest \\
\cline { 4 - 6 } & & & & & Capture site $^{a}$ \\
Santa Catarina Island & 10 & $50 \%$ & 1 & $4(3)$ & $5(2)$ \\
North region & 112 & $20.5 \%$ & $37(6)$ & $20(8)$ & $55(9)$ \\
Central region & 15 & $13.3 \%$ & - & - & $15(2)$ \\
South region & 137 & $21.9 \%^{b}$ & $38(6)$ & $24(11)$ & $75(13)$ \\
Sub total & 62 & $45.2 \%^{b}$ & - & - & $62(28)$ \\
Arvoredo Island & 199 & & $38(6)$ & $24(11)$ & $137(41)$ \\
\hline Total & & &
\end{tabular}

$a$ : number of opossums captured (number of $T$. cruzi infected animals); $b$ : significant $(\mathrm{p}<0.001)$

opossums in the AI was significantly higher than in SCI $(\mathrm{p}<0.001)$.

From a total of 35 opossums examined, tagged and released in the same capturing site in the AI, six females were recaptured. One female, originally negative for $T$. cruzi infection by all methods, became infected within a six month period as revealed by xenodiagnosis and hemoculture indicating active transmission in the AI. Following the method used by Miles (1976), six opossums were monitored in the AI. Two animals were recovered and their nests, one in a tree hole and the other under a rock formation, were negative for triatomines. Two other line ends were found in rocks and two were disrupted. Neither the 12 rodents (Oryzomys sp.) captured in this island nor all six soldiers of the Brazilian navy living there were positive for $T$. cruzi infection.

A total of eight $P$. megistus (five female adults and three nymphs) were captured in the AI during the whole study. The five females were captured using light traps, while the three nymphs were found in an opossum nest in a tree hole. Six triatomines (three nymphs and three adults) revealed the presence of T. cruzi in their feces. Two others were collected by Navy soldiers and preserved in alcohol.

In contrast, the search for triatomines in SCI revealed the presence of $P$. megistus in the sylvatic environment, where 268 nymphs and six adults were collected, as well as in human dwellings where 305 nymphs and 24 adults were captured. The $T$. cruzi infection rate among these triatomines was $86.1 \%$ and $55.3 \%$, respectively.

During this study, 38 T. cruzi strains were isolated from D. marsupialis and 28 strains were isolated from P. megistus collected in both SCI and
AI. These strains were already characterized by Steindel et al. $(1993,1995)$ by biological, biochemical and molecular methods.

Despite the existence of $T$. rangeli in Santa Catarina (Grisard et al. 1999), none of the animals examined during this study were infected by this parasite.

\section{DISCUSSION}

Opossums from the genus Didelphis have a wide distribution in South America, being frequently observed in close association with triatomines and human dwellings in both sylvatic and urban areas. Rodents and marsupials, are not only the most important blood source for several triatomine species, but also their major source of T. cruzi infection (Rocha e Silva et al. 1975). Studies on T. cruzi infection in Didelphis sp. in different regions of Brazil revealed infection rates varying from $20.6 \%$ to $37.9 \%$ (Guimarães \& Jansen 1943, Miles 1976, Mello 1982, Fernandes et al. 1991). In the present work T. cruzi infection rates of $21.9 \%$ and $45.2 \%$ were found in D. marsupialis captured in the Santa Catarina and Arvoredo Islands, respectively.

Previous studies reported the association of $T$. cruzi infected triatomines (P. megistus and $R$. domesticus) with rodent and marsupial nests in wild areas of the SCI (Leal et al. 1961, Schlemper Jr et al. 1985). Also, the association of $P$. megistus with $D$. marsupialis in artificial ecotopes, including human-made dwellings in SCI, has been reported (Steindel et al. 1994). Similar report was made by Forattini et al. (1982) in the State of São Paulo.

Using the precipitin test to evaluate the food source of these triatomines, Steindel et al. (1994) have found that $80.6 \%$ of the 31 adult P. megistus 
captured in artificial ecotopes fed on humans. Moreover, T. cruzi infection was detected in 55.3\% of these triatomines.

In the present study, 62 out of $137 \mathrm{D}$. marsupialis $(45.2 \%)$ were captured in human dwellings in the SCI. Natural T. cruzi infection was confirmed in 17 (27.4\%) of these opossums.

The massive destruction of the original Atlantic forest in the SCI allied to the construction of houses close to the remaining forest made contact of humans with both opossums and $P$. megistus frequent. In contrast, AI is a federal reserve which have a well conserved Atlantic forest. Besides the five Brazilian Navy houses, no other human-made dwelling is present in this island where $T$. cruzi circulates among animals in a sylvatic environment. Moreover, opossums meat is still appreciated as an exotic food by native inhabitants of SCI.

The presence of $T$. cruzi infected triatomines and opossums in human dwellings in the SCI, as well as the detection of both human and opossum blood in T. cruzi-infected triatomines, indicates the risk of transmission of this parasite to humans. The same epidemiological situation was observed in the State of São Paulo when Litvoc et al. (1990) detected the presence of P. megistus in D. azarae nests and an infection rate of $47.8 \%$ of these opossums by $T$. cruzi.

A related behavior was observed by Telford $\mathrm{Jr}$ and Tonn (1982) in the upper llanos of Venezuela. Studying the $T$. cruzi dynamics in D. marsupialis, these authors observed a prevalence of $55.2 \%$ and a close relation of this animal with $R$. prolixus and human dwellings.

In contrast, an extensive serological survey carried out among 5,831 inhabitants of the SCI revealed a prevalence of infection of $0.034 \%$ (Carobrez et al. 1992). Thus, T. cruzi transmission in SCI occurs almost exclusively between $P$. megistus and D. marsupialis in the sylvatic environment. Moreover, SCI presents a low density of $P$. megistus found in artificial ecotopes, such as human-made dwellings (Steindel et al. 1994).

Despite the low prevalence in humans, the occurrence of naturally infected reservoirs and vectors in domestic environments at SCI does not rule out the possibility of finding human infection in this habitat.

A comparison of serological and parasitological tests to detect $T$. cruzi infection in $116 D$. albiventris captured in Bambuí, State of Minas Gerais, revealed that $97.7 \%$ of the infected animals were positive in both tests (Fernandes et al. 1990). Having used fresh and Giemsa-stained smears, hemoculture and xenodiagnosis to detect $T$. cruzi infection in opossums during this study, 34 negative animals were kept in the laboratory and fol- lowed during two months by parasitological and serological tests (indirect immunofluorescence). Since only one opossum was positive by either tests, we conclude that $T$. cruzi infection in opossums can be easily detected by using parasitological methods.

T. cruzi infection rate among D. marsupialis captured in the AI, which is geographically isolated and has a well conserved forest, was $45.2 \%$. In contrast with the high $T$. cruzi infection rate among opossums, triatomines are scarce. $P$. megistus was the only species captured in this island and all six triatomines examined were positive for T. cruzi. Moreover, opossum blood was detected in all three nymphs submitted to precipitin tests.

Two out of 28 (7.1\%) opossums also presented $T$. cruzi in their scent glands. Natural T. cruzi infection in D. albiventris and D. marsupialis scent glands has been demonstrated by Fernandes et al. (1989) and by Naiff et al. (1987) which have detected one positive gland out of 20 animals examined, and in one out of 90, respectively. Our results are in agreement with these previous reports, confirming the low occurrence of naturally T. cruzipositive scent glands in D. marsupialis. Moreover, we cannot infer that this possible transmission mechanism can be responsible for the high prevalence of $T$. cruzi in opossums of the AI. Other possibilities of vertical transmission such as milk feeding were studied and discarded by Telford Jr and Tonn (1982) and by Deane et al. (1986).

Characterization of $68 \mathrm{~T}$. cruzi strains by biological, biochemical and molecular methods showed that strains from AI produce sub-patent parasitemia in Swiss mice and a high homogeneity of isoenzyme and randomly amplified polymorphic DNA profiles. Based on the same markers, strains isolated in SCI revealed a higher heterogeneity than that observed among strains isolated in the AI (Steindel et al. 1995).

These results can be explained by the geographical isolation of the AI, where T. cruzi strains circulate almost exclusively among opossums. On the other hand, in the SCI T. cruzi have been isolated from triatomines and a wide variety of mammals, rodents and marsupials which may explain the higher heterogeneity observed.

The presence of $T$. cruzi in the AI opossums scent glands may suggest a high adaptation of some parasite strains and the opossum. Deane et al. (1984, 1986) observed that only a few $T$. cruzi strains were able to infect the scent glands under controled conditions.

Due to the opossums omnivorous habits, another way of infection considered was the ingestion of $T$. cruzi-infected rodents. All 12 Oryzomys 
sp. captured and submitted to parasitological tests were negative for $T$. cruzi infection. We have not discarded this possibility, however, it appears to be infrequent.

Experimental infection of newborn $D$. marsupialis with $T$. cruzi strains from $\mathrm{AI}$ and SCI showed a long-term blood parasitemia. The presence of T. cruzi was observed in 50\% of the scent glands of these animals after a two to three months period only in opossums experimentally infected with strains isolated from AI (M Steindel, unpublished data).

Infection of the opossum scent glands suggests a high degree of host-parasite adaptation of some T. cruzi strains. Trypanosomes derived from opossums scent glands proved to be infective for mice and opossums under experimental conditions (Deane et al. 1986, Steindel et al. 1988).

Another hypothesis that may explain the high T. cruzi prevalence among opossums in the AI that must be considered is the ingestion of T. cruzi-infected triatomines. The known insectivorous habits of these animals have already been demonstrated (Zeledon 1974) and must be considered as a possible $T$. cruzi infection source to the opossums in the AI. The low number of triatomines found in the AI did not explain the high prevalence of $T$. cruzi among opossums. However, more studies must be performed in order to better evaluate the triatomine density in this island. The existence of an alternative or unusual transmission mechanism of T. cruzi between D. marsupialis in the AI cannot be neglected.

Although Santa Catarina is not an endemic area for human Chagas disease, the presence of $D$. marsupialis infected with $T$. cruzi in human dwellings in the SCI must be considered as an important risk factor for Chagas disease. Moreover, serving as blood and $T$. cruzi infection source to $P$. megistus, these opossums are acting as links between the domestic and sylvatic transmission cycles.

\section{ACKNOWLEDGEMENTS}

To Fundação Nacional de Saúde, Santa Catarina, and Marinha do Brasil, AgCP Florianópolis, for their valuable help during field works.

\section{REFERENCES}

Barretto MP, Siqueira AF, Corrêa FMA, Ferriolli Filho F, Carvalheiro JR 1964. Estudos sobre reservatórios e vetores silvestres do Trypanosoma cruzi. VII: Investigações sobre a infecção natural de gambás por tripanossomos semelhantes ao T. cruzi. Rev Bras Biol 24: 289-300.

Bronfen E, Rocha FSA, Machado GBN, Perillo MM, Romanha AJ, Chiari E 1989. Isolamento de amostras do Trypanosoma cruzi por xenodiagnóstico e hemocultura de pacientes na fase crônica da doença de Chagas. Mem Inst Oswaldo Cruz 84: 237-240.

Carobrez SG, Ishida MMI, Steindel M, Carvalho Pinto CJ, Grisard EC, Toma HK, Rosa R, Schlemper Jr $B R$ 1992. Investigation of the human authochthonous chagasic infection in Santa Catarina Island, Santa Catarina State, Brazil. Mem Inst Oswaldo Cruz 87 (Suppl. I): 220.

Deane MP, Lenzi HL, Jansen AM 1984. Trypanosoma cruzi: vertebrate and invertebrate cycles in the same mammal host, the opossum Didelphis marsupialis. Mem Inst Oswaldo Cruz 70: 513-515.

Deane MP, Lenzi HL, Jansen AM 1986. Double development cycle of Trypanosoma cruzi in the opossum. Parasitol Today 2: 146-147.

Fernandes AJ, Chiari E, Chiari CA 1990. Diagnóstico de infecção pelo Trypanosoma cruzi em gambás naturalmente infectados, pela reação de imunofluorescência indireta. Mem Inst Oswaldo Cruz 23: 157-161.

Fernandes AJ, Chiari E, Ribeiro Rodrigues R, Dias JCP, Romanha AJ 1991. The importance of the opossum (Didelphis albiventris) as a reservoir for Trypanosoma cruzi in Bambuí, Minas Gerais State. Mem Inst Oswaldo Cruz 86: 81-85.

Fernandes AJ, Diotaiuti L, Dias JCP, Romanha AJ, Chiari E 1989. Infecção natural das glândulas anais de gambás (Didelphis albiventris) pelo Trypanosoma cruzi no município de Bambuí - MG. Mem Inst Oswaldo Cruz 84: 87-93.

Forattini OP, Barata JMS, Dellatorre CC, Buralli GM 1982. Nota sobre a domiciliação de Panstrongylus megistus no litoral sul do Estado de São Paulo. Rev Saú Públ São Paulo 16: 127-131.

Grisard EC, Steindel M, Guarneri AA, Eger-Mangrich I, Campbell DA, Romanha AJ 1999. Characterization of Trypanosoma rangeli strains isolated in Central and South America: An overview. Mem Inst Oswaldo Cruz 94: 203-209.

Guimarães FN, Jansen G 1943. Novo transmissor silvestre do Trypanosoma (Schizotrypanum) cruzi (Chagas, 1909). Mem Inst Oswaldo Cruz 38: 437-441.

Leal H, Ferreira Neto JA, Martins CM 1961. Dados ecológicos sobre triatomíneos silvestres na Ilha de Santa Catarina (Brasil). Rev Inst Med Trop São Paulo 3: 213-220.

Litvoc J, Goldbaum M, Silva GR 1990. Determinantes do processo de infestação domiciliar por Panstrongylus megistus: o papel da habitação e do desmatamento. Rev Inst Med Trop São Paulo 32: 443-449.

Luz ZMP, Coutinho MG, Cançado JR, Krettli AU 1994. Hemocultura: técnica sensível na detecção do Trypanosoma cruzi em pacientes chagásicos na fase crônica da doença de chagas. Rev Soc Bras Med Trop 27: $143-148$.

Mello DA 1982. Roedores, marsupiais e triatomíneos silvestres capturados no município de Mambaí Goiás. Infecção natural pelo Trypanosoma cruzi.Rev Saú Públ São Paulo 16: 282-291.

Miles MA 1976. A simple method of tracking mammals and locating triatominae vectors of Trypano- 
soma cruzi in Amazon forest. Am J Trop Med Hyg 25: 671-674.

Naiff RD, Naiff MR, Barrett TV, Arias JR 1987. Trypanosoma cruzi nas glândulas anais de Didelphis marsupialis: primeiro registro de infecções naturais, $10^{\circ}$ Congresso da Sociedade Brasileira de Parasitologia, Salvador, p. 234.

Rocha e Silva EO, Andrade JCR, Lima AR 1975. Importância dos animais sinantrópicos no controle da endemia chagásica. Rev Saú Públ São Paulo 9: 371-381.

Schlemper Jr BR, Steindel M, Gargioni R, Farias CJM, Oliveira R, Trianon JAX 1985. Reservatórios e vetores silvestres do Trypanosoma cruzi e suas relações com o domicílio humano na Ilha de Santa Catarina. Arq Cat Med 14: 91-96.

Steindel M, Dias Neto E, Menezes CLP, Romanha AJ, Simpson AJG 1993. Random amplified polymorphic DNA analysis of Trypanosoma cruzi strains. Mol Biochem Parasitol 60: 71-80.

Steindel M, Scholz AF, Toma HK, Schlemper Jr BR 1988. Presence of Trypanosoma cruzi in the anal glands of naturally infected opossum (Didelphis marsupialis) in the State of Santa Catarina, Brazil. Mem Inst Oswaldo Cruz 83: 135-137.

Steindel M, Toma HK, Carvalho Pinto CJ, Grisard EC, Schlemper Jr BR 1994. Colonização de ecótopos artificiais pelo Panstrongylus megistus na Ilha de
Santa Catarina, Florianópolis, Santa Catarina, Brasil. Rev Inst Med Trop São Paulo 36: 43-50.

Steindel M, Toma HK, Ishida MMI, Murta SMF, Carvalho Pinto CJ, Grisard EC, Schlemper Jr BR, Ribeiro Rodrigues R, Romanha AJ 1995. Biological and isoenzymatic characterization of Trypanosoma cruzi strains isolated from sylvatic reservoirs and vectors from the State of Santa Catarina, Southern Brazil. Acta Trop 60: 167-177.

Telford Jr SR, Tonn RJ 1982. Dinamica de Trypanosoma cruzi en poblaciones de un reservorio primario, Didelphis marsupialis, en los llanos altos de Venezuela. Bol Ofic Sanit Panamericana 93: 341-364.

Travi BL, Jaramillo C, Montoya J, Segura I, Zea A, Gonçalves A, Velez ID 1994. Didelphis marsupialis, an important reservoir of Trypanosoma (Schizotrypanum) cruzi and Leishmania (Leishmania) chagasi in Colombia. Am J Trop Med Hyg 50: 557 - 561.

Zeledon R 1974. Epidemiology, modes of transmission and reservoir hosts of Chagas' disease. In Trypanosomiasis and Leishmaniasis with Special Reference to Chagas Disease, Ciba Foundation Symposium 20 (new series), p. 51-77.

Zeledon R, Solano G, Saenz G, Swatswelder JC 1970. Wild reservoir of Trypanosoma (Schizotrypanum) cruzi with special mention of the opossum Didelphis marsupialis and its role in the epidemiology of Chagas disease in an endemic area of Costa Rica. $J$ Parasitol 56: 38-47. 